\title{
Intizar
}

Vol. 26, No. 1, Juni 2020

Website: http://jurnal.radenfatah.ac.id/index.php/intizar

ISSN 1412-1697, e-ISSN 2477-3816

\section{Kesiapan Madrasah untuk Keberlanjutan Proses Pendidikan Perspektif Teologi Perubahan di Era Industri 4.0}

\author{
Abdul Hadi \\ Universitas Islam Negeri Raden Fatah Palembang, Indonesia, abd.hadhy@radenfatah.ac.id
}

DOI: doi.org/10.19109/intizar.v26i1.5845

\begin{abstract}
Abstrak
Penelitian ini bertujuan untuk menganalisis bagaimana kesiapan madrasah di era industri 4.0 agar tetap eksis dan berlanjut dalam usaha mencerdaskan anak bangsa. Metode penelitian yang digunakan adalah kualitatif dengan pendekatan continuity and change. Pendekatan ini memandang bahwa fenomena sosial, termasuk tradisi sistem pendidikan madrasah sekarang ini merupakan kesinambungan dari tradisi yang ada sebelumnya, walaupun seringkali mengalami beberapa perubahan dan pengembangan. Penelitian ini menyatakan bahwa pada prinsipnya madrasah semestinya mempunyai potensi besar untuk berkembang karena mempunyai social power yang dimilikinya. Madrasah yang eksistensinya berada di wilayah yang memiliki masyarakat muslim terbesar di dunia. Kondisi tersebut jelas mempunyai hubungan vertikal antara madrasah dengan masyarakat sebagai objek transformasi dalam mewariskan serta melestarikan eksistensi keyakinan dan nilai keislaman.
\end{abstract}

Kata Kunci : Pendidikan Islam, Revolusi Industri 4.0, Madrasah

\begin{abstract}
This study aims to analyze how the readiness of madrasa in the industrial era 4.0 to exist and continue in an effort to educate the nation's children. The research method used is qualitative with a continuity and change approach. This approach considers that social phenomena, including the current tradition of the madrasah education system, are a continuation of the previous traditions, although they often undergo some changes and developments. This research states that in principle, madrasas should have great potential for development because they have the social power they have. Madrasas whose existence are in areas that have the largest Muslim community in the world. This condition clearly has a vertical relationship between madrasas and society as objects of transformation in inheriting and preserving the existence of Islamic beliefs and values.
\end{abstract}

Keywords: Islamic education, The 4.0 Industrial Revolution, Madrasa

\section{Pendahuluan}

Penelitian ini mendukung Martin van Bruinessen (1994) dalam studinya tentang "Pesantren dan Kitab Kuning" yang telah mengurai bahwa lembaga pendidikan Islam berupa madrasah dan pesantren memiliki dinamika yang tinggi dalam wacana intelektual maupun dalam memberikan respons perubahan terhadap persoalan-persoalan keagamaan, sosial, dan politik di Indonesia. Demikian juga Hiroko Horikoshi (1976) dalam studinya tentang "Kyai dan Perubahan Sosial" telah berhasil menunjukkan secara jelas bahwa lembaga pendidikan Islam tradisional (label untuk pesantren dan madrasah) di Indonesia bukan merupakan kelompok yang menghambat atau antipati terhadap perubahan sosial yang tengah terjadi, tetapi justru merupakan pelopor dan perubahan itu sendiri.

Madrasah merupakan salah satu bentuk Lembaga pendidikan Islam berciri khas keIndonesia-an, banyak mengalami dilema di era perkembangan global. Penyesuaian kemampuan madrasah harus didorong untuk percepatan budaya supaya sesuai dengan perkembangan kebutuhan masyarakat. Cukup banyak madrasah atau pesantren mulai ditinggal calon siswa atau santri karena dianggap tidak mampu menjanjikan output yang 
unggul. Eksistensi madrasah sudah masuk ke dalam pusaran persaingan global. Untuk sebagian kecil pada posisi unggul, terutama madrasah negeri atau bila swasta ditopang yayasan yang mempunyai sumber finansial yang memadai. Namun masih banyak madrasah berada pada posisi "pinggiran" yang ada untuk jadi pilihan calon santri atau murid sebagai alternatif apabila tidak lulus di sekolah unggulan atau negeri, atau daripada tidak sekolah. Fenomena tersebut terjadi di banyak wilayah nusantara, dan ini menimbulkan keresahan para pengelola madrasah, dan sebenarnya ini disadari akan tetapi masih terjadi ketidakberdayaan baik aspek manajemen, sumber daya manusia, dan keuangan.

Salah satu isu utama adalah konsep pemikiran para pengelola madrasah dalam menghadapi perubahan dan perkembangan global. Pada periode awal kehadiran madrasah merupakan lembaga pendidikan masyarakat yang dicap berbobot untuk bidang dakwah Islam. Kehadiran pesantren dan madrasah lazimnya didahului sebagai sejarah "perang nilai". Yakni madrasah atau pesantren yang didirikan dengan kondisi masyarakat sekitarnya, dan ini berakhir pada kemenangan di pihak madrasah atau pesantren. Mereka diterima untuk eksis di masyarakat dan jadi panutan dalam kehidupan moral dan pelestarian nilai-nilai (Mastuhu, 1994). Kondisi itu terkadang diikuti dengan kehadiran santri atau siswa yang berasal dari daerah lain yang jauh, dan di situ terjadi interaksi budaya antarsuku dan masyarakat yang secara tersirat telah memupuk rasa kebhinekaan dan cinta tanah air dalam perkembangan sejarah sosial di nusantara. Kondisi tersebut yang terjadi di era perkembangan dan pertumbuhannya di Indonesia. Namun untuk kondisi sekarang belum terpetakan secara jelas apabila dikaitkan dengan datangnya era revolusi Industri 4.0. Data terakhir jumlah madrasah di Indonesia dapat dilihat pada tabel 1 .
Tabel 1. Rekapitulasi Jumlah Madrasah Tahun

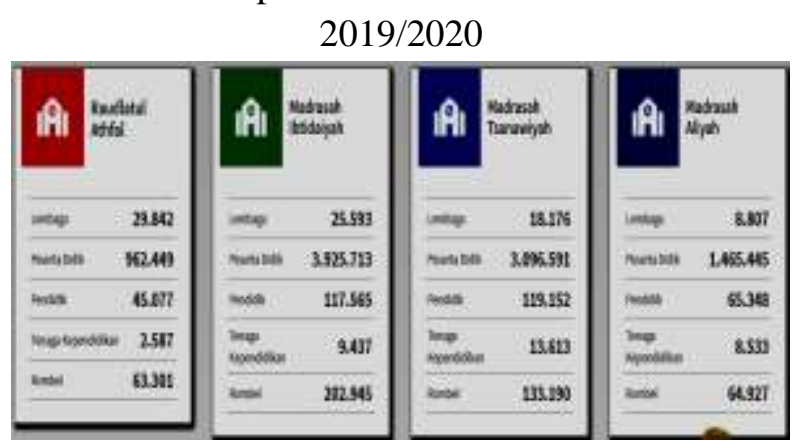

Dalam pasang surut kajian studi Islam di Indonesia, muncul kecenderungan kuat untuk menggunakan dikotomi antara Islam tradisional dengan Islam modern sebagai objek analisis dalam memahami perkembangan Islam. Akan tetapi, tidak jarang terjadi bahwa kajian Islam tradisional banyak dikesampingkan, atau kurang mendapat perhatian secara proporsional dibandingkan dengan jumlah penganut Islam tradisional dan kuatnya pengaruh Islam tradisional dalam kehidupan beragama di Indonesia. Bahkan kajian tentang Islam tradisional terkadang digunakan perspektif serta standar Islam modern, sehingga menghasilkan kesalahan dalam memahami kondisi sebenarnya tentang Islam tradisional. Inilah oleh Woodward dikategorikan pendekatan teologis untuk kajian sosiologis dan historis. Misalnya yang dilakukan oleh Noer dan Alfian yang berorientasi modernis dalam membahas Islam tradisional. Menurut Woodward (1996) mereka menggunakan ortodoksi modernisme dan heterodoksi tradisionalisme Islam di Nusantara.

Hal serupa juga terjadi pada karya Geertz yang menyimpulkan Islam tradisional sebagai bentuk dan ciri yang serupa varian kelompok abangan yang mengakomodasi elemen non-Islam. Geertz (1960) boleh jadi diinspirasi oleh pandangan Islam modern yang disinyalir sebagai Islam Islam murni. Geertz boleh jadi mendapat pengaruh pemikiran Weber lebih menekankan aspek rasional. Dalam banyak pandangan, pengikut Islam tradisional terkadang dianggap bagian dari masyarakat kolot, pasif, serta terbelakang, dan juga mempunyai sikap antipati pada kemajuan dan perubahan.

Akan tetapi, beberapa studi tentang Islam tradisional yang berusaha memahami hakekat Islam tradisional secara benar dan utuh, dengan 
menggunakan pendekatan yang lebih menekankan pada perspektif penganut Islam tradisional itu sendiri telah mulai dilakukan. Dhofier (1985) dengan karya monumentalnya "Tradisi Pesantren: Studi Tentang Pandangan Hidup Kyai”, merupakan tokoh utama yang merintis studi tentang Islam tradisional dengan pendekatan yang menekankan pada perspektif yang digunakan oleh penganut Islam tradisional itu sendiri. Studi ini telah menunjukkan adanya vitalitas Islam tradisional di Jawa dan adanya peranan kyai dalam mempertahankannya, yang dikaitannya dengan perubahan-perubahan yang terjadi dalam masyarakat Jawa.

Analisis dikotomi Islam tradisional-Islam modern seringkali dihubungkan dengan dikhotomi desa-kota, sehingga Islam tradisional identik dengan Islam masyarakat pedesaan, dan Islam modern identik dengan Islam masyarakat perkotaan. Demikian studi perkembangan Islam di Indonesia yang telah dilakukan oleh H. J. Benda (1987), Lance Castles (1957), Alfian (1970) bahwa orientasi Islam tradisional di Jawa dan luar Jawa terdapat persamaan, yakni menganut paham Asy'ari dan Maturidi dalam teologi, fikih mazhab Syafi'i dan alGhazali dalam bidang tasawuf. Namun dalam hal pusat perkembangan Islam tradisional, terdapat perbedaan antara Jawa dan Sumatera. Bila perkembangan Islam tradisional di Jawa berpusat pada masyarakat daerah pedesaan, maka di Sumatera seperti di Palembang, Islam tradisional berpusat dalam masyarakat perkotaan (Hadi, Budianto, Otoman, Mikail, \& Syarifudin, 2020).

Industri 4.0 atau disebut dengan istilah "disruptive innovation", yang dicetuskan oleh Christensen (1995), dengan tulisan artikel beliau pada jurnal Harvard Business Review dengan judul "Disruptive Technologies: Catching the Wave". Kemudian menjadi proyek strategis teknologi moderen Jerman dengan komputerisasi pabrik yang dominan. Istilah ini Industri 4.0 didengungkan lagi pada acara Hannover Fair 2011 dan 2012 memberikan rekomendasi implementasi konsep Industri 4.0 kepada pemerintah Jerman. Industri 4.0 diskemakan membentuk "pabrik cerdas" berstruktur moduler, sistem siber-fisik lewat internet untuk segala, sistem komunikasi yang bekerjasama secara simultan dan secara bersamaan.
Membicarakan tentang era revolusi industri 4.0, menurut Jack Ma pada pertemuan World Economic Forum 2018, mengungkapkan bahwa pendidikan menjadi tantangan berat abad ini. Apabila tidak merubah metode mendidik dan proses pembelajaran, maka 30 tahun yang akan datang mengalami dilema. Jelas sekali apabila proses pendidikan yang hanya didominasi muatan pengetahuan yang mengesampingkan aspek sikap dan keterampilan maka dapat menghasilkan output yang tertinggal menghadapi kompetisi dengan mesin. Muatan kognitif yang dominan dalam belajar harus diperbaiki agar produk lulusannya mempunyai keunggulan kecerdasan mesin serta di sisi lain mempunyai sikap bijak untuk kemaslahatan masyakarat (Reynarah, 2015).

Berbagai literatur terkait era Industri 4.0 hubungannya dengan pendidikan sebenarnya sudah banyak. Diantara beberapa tulisan seperti, Hussin (2018) yang menulis artikel Gagasan untuk mengajar di era Industri 4.0. Laporan Tim United Nations Special Envoy, 2016 yang dipublikasi dengan judul "The Learning Generation: Investing in Education for a Changing World" (Steer, 2016). Artikel yang ditulis oleh Puncreobutr (2016), tentang Pendidikan Era 4.0 dan tantangan dalam pembelajaran. Selain itu ada ada artikel yang ditulis Sivathanu dan Pillai (2018) terkait Smart Human Resources di era 4.0. Shahroom (2018) terkait Industrial Revolution 4.0 and Education.

Sistem pendidikan sangat memerlukan gerakan kebaruan untuk merespon perkembangan dan perubahan. Literasi baru yang dicanangkan pemerintah Indonesia setidaknya dapat membentuk alumni yang kompetitif pada peningkatan kemampuan membaca, menulis, dan matematika. Pada paragraf ini muncul pertanyaan, apakah pendidikan di Indonesia atau dalam lingkup lembaga pendidikan Islam sudah siap? tentu jawabannya tidak dapat dinyatakan tanpa data dan informasi yang jelas dan lengkap. Berdasarkan pertanyaan besar tersebut, penelitian ini akan memfokuskan pada kajian untuk menjawab kesiapan madrasah di era industry 4.0 pada aspek kultur pengelola madrasah dengan melihat pada gambaran kondisi madrasah di Indonesia. 


\section{Metode Penelitian}

Kajian ini menganalisis perubahan Kultur pengelola madrasah di era Industri 4.0 atau tren era otomasi. Menggunakan kerangka teori continuity and change, sebagaimana digunakan oleh Dhofier dalam meneliti tradisi pesantren dan juga Azra dalam meneliti jaringan ulama. Pendekatan continuity and change memandang bahwa fenomena sosial, termasuk tradisi sistem pendidikan madrasah sekarang ini merupakan kesinambungan dari tradisi yang ada sebelumnya, walaupun seringkali mengalami beberapa perubahan dan pengembangan. Pendekatan ini merupakan kritik atas pendekatan dikotomi tradisional dan modern dalam memahami pesantren di Indonesia, yang terbukti tidak mampu memahami banyaknya varian pesantren yang berkembang pesat akhir-akhir ini akibat perubahan sosial yang terjadi. Selain itu, pendekatan ini barangkali menjadi alternatif baru sebagai pendekatan dalam studi-studi tentang madrasah maupun juga pesantren di Indonesia.

Pendekatan continuity and change tersebut kemudian digunakan untuk membuat struktur penelitian. Sedangkan untuk menjelaskan isi dari struktur tersebut pada prinsipnya menggunakan pendekatan pendidikan sebagai sistem. Oleh karena itu, Penelitian ini pada prinsipnya merupakan penelitian sosial di bidang pendidikan atau lebih tepat digolongkan dalam bidang sosiologi pendidikan. Sosiologi pendidikan memandang bahwa realitas pendidikan sangat berkait erat dengan realitas sosial yang terjadi, serta berinteraksi dengan mengambil bentuk tertentu yang nantinya melahirkan karakteristik masing-masing (Brown, 1961).

\section{Hasil dan Pembahasan}

\section{Kebutuhan Madrasah yang Kompetitif}

Madrasah berdasarkan kondisi untuk eksistensi sebagai lembaga pendidian unggulan berdasarkan penilaian dan perhatian atau pandangan masyarakat. Apabila madrasah yang mampu memenuhi harapan masyarakat luas maka ini menjadi indikator sebagai "madrasah favorit" atau "madrasah unggulan" atau diistilahkan sebagai "madrasah model". Untuk madrasah yang banyak diminati akan mendorong munculnya kompetisi di kalangan orang tua calon siswa untuk mendaftar anaknya di lembaga tersebut. Madrasah favorit sangat diminati secara luas dan menjadi tren untuk dikembangkan. Kondisi ini berdasarkan pada perubahan sosial di masyarakat Indonesia (Zasmadi, 2002). Sebagaimana halnya teori yang ditawarkan Etzioni, tentang teori masyarakat aktif yaitu masyarakat yang mengikuti perkembangan dan perubahan. Dalam mengikuti perubahan ini upaya para pengelola adalah dengan maksimal melakukan pemenuhan kebutuhan tuntutan standar madrasah unggul. Upaya itu yakni 1) menyiapkan suasana kegiatan pembelajaran berupa kondisi kelas yang asri, nyaman, serta kondusif; 2) model proses pembelajaran dengan sistem aktif, dan kreatif, serta inovatif; dan 3) proses belajar berbasis pada penggunaan teknologi informasi (Hasyim, 2009).

Kemunculan madrasah unggulan sudah mulai berkembang dengan berbagai konsep yang sangat bervariasi, karena itu mendorong munculnya beberapa model. Menurut Moedjiarto (2007), lembaga pendidikan unggulan bermunculan saat ini dapat dikategorikan dalam beberapa tipe, antara lain: 1) input siswa/i yang unggul, proses pembelajaran yang intensif dan luar biasa; 2) unggul dalam fasilitas, dengan fasilitas yang lengkap dan lazimnya berbiaya tinggi. Sekolah ataupun madrasah dengan fasilitas seperti itu dimaksudkan agar daya tahan siswa untuk belajar menjadi lebih berkualitas. Adanya fasilitas itu termasuk gurunya juga pilihan, dengan fasilitas lengkap dan guru bermutu maka lulusannya juga bermutu tinggi atau prestasi akademik siswa yang unggul; dan 3) sekolah unggul dengan penekanan iklim belajar yang positif. Kondisi itu mendorong sekolah atau madrasah mampu mendorong terjadinya proses siswa dari input yang rendah, menghasilkan lulusan berkualitas.

Berdasarkan konsep yang disampaikan Azra (2002), "sekolah Islam unggulan" atau "madrasah unggul" dicap sebagai "sekolah elit Islam" karena berbagai alasan: "sekolah elit" perspektif akademis karena hanya siswa terbaik yang dapat diterima di sekolah tersebut, serta harus melewati proses ujian yang kompetitif; Guru atau tenaga pengajar merupakan sumber daya manusia yang telah diseleksi kompetitif dengan memenuhi persyaratan ketat; Sekolah mempunyai sarana 
prasarana lengkap, berupa: perpustakaan, laboratorium, fasilitas komputer, tempat ibadah, lapangan olahraga. Dengan fasilitas itu mampu mendorong siswa dan sekolah menjadi unggul di bidang akademis bila dibandingkan lembaga pendidikan lain, termasuk sekolah negeri.

Merujuk pada kategorisasi tersebut sebenarnya madrasah unggul merupakan lembaga pendidikan Islam yang mempunyai program unggulan. Indikatornya antara lain; memiliki kemampuan berprestasi tingkat nasional bahkan internasional di bidang penguasaan ilmu pengetahuan dan teknologi disertai tambahan ciri khasnya sebagai lembaga pendidikan Islam yakni berakhlak baik (akhlakul karimah). Keberadaan madrasah unggul pada dasarnya telah mampu memberikan daya tarik tersediri bagi masyarakat meskipun terkadang dengan biaya yang lebih mahal. Kondisi tersebut terjadi karena dianggap mampu menghasikan lulusan atau alumni berkualitas secara akademis ataupun non akademis.

Lembaga Pendidikan Islam mengalami perkembangan dinamis perspektif lintasan sejarah sosial masyarakat Islam Indonesia. Dalam sejarah, konsep dan implementasi nilai-nilai pendidikan Islam sangat dipengaruhi berbagai perkembangan sosial dalam varian lokus ruang serta waktu (Alam, 2012). Inilah menurut para peneliti menarik dibahas terutama terkait pengaruh perubahan sosial terhadap perkembangan pendidikan Islam (Maksudin, 2008). Perspektif sosiologis dimaksud yaitu sisi transformasi nilai dan norma Islam pada konteks sosio-institusional, dan ia menjadi bagian dari kehidupan sosial masyarakat.

Untuk menjadi lembaga pendidikan yang unggul, mandiri dan kompetitif bukanlah tugas ringan. Tipe madrasah unggul di Indonesia sejatinya sudah bermunculan di beberapa wilayah. Madrasah yang telah memperoleh predikat berprestasi pada dasarnya ditopang pendukung eksternal. Penopang itu adalah pemerintah apabila madrasahnya negeri atau bila swasta ditopang pihak yayasan. Madrasah yang tidak mempunyai pendukung eksternal kuat, mengalami kondisi berjalan seadanya. Kekuatan utama madrasah dan pesantren secara umum adalah kekuatan idealisme, dan semangat pengabdian, serta keinginan untuk berkorban. Kondisi inilah membuat madrasah kebanyakan masih tetap eksis, meski didera kesulitan untuk maju dan berakselerasi dengan perubahan. Inilah bagian sosial madrasah, yang didirikan dan dilestarikan masyarakat yang ada di lingkungan sekitarnya. Kondisi itu mengalami perubahan seiring perkembangan waktu dan arus perkembangan global, yang dengan kondisi itu madrasah dan lingkungan penyokongnya juga berubah dan berkembang.

\section{Perubahan dan Sistem Nilai di Lembaga Madrasah}

Di era global proses internalisasi sistem nilai tidak terjadi dengan model paksaan. Sistem nilai masuk ke budaya masyarakat lazimnya melalui adopsi budaya yang lembut dan sedikit demi sedikit. Dengan kata lain globalisasi telah mendorong terbentuknya kondisi budaya yang diklaim baik dengan penyesuaian standar serta dikonstruksi dan dicitrakan seolah memang diperlukan masyarakat. Kondisi itulah mendorong dari sisi internal masyarakat menerima dan mengimplementasikan nilai-nilai tersebut ke dalam kehidupan masyarakat bahkan pribadi (Hamad, 2004). Terkait dengan hal tersebut masyarakat tidak menganggap sistem nilai baru yang diadopsi itu adalah sebuah bangunan dominasi antar satu sistem terhadap lainnya. Munculnya kebanggaan dalam suatu masyarakat apabila berbuat dengan nilai baru serta meninggalkan budaya yang lama mereka disebabkan tidak relevan dengan situasi masa sekarang (Maulana \& Irfan, 2010). Dewasa ini, kita dapat mengakses dan menemukan dengan mudah berbagai gagasan dan informasi baru terkait budaya. Misalnya bidang literatur, makanan, fashion dan lainnya. Perkembangan produk elektronik seperti telepon genggam, televisi, dan internet mengindikasikan komunikasi secara global berlangsung cepat, demikian juga pergerakan massa semacam pariwisata memungkinkan terjadinya interaksi banyak hal dari budaya yang berbeda (Esposito, Fasching, \& Lewis, 2007; Hefner, 2007).

Globalisasi tidak dapat dihindari dan tentu membawa pengaruh terhadap kehidupan suatu negara termasuk negara kita Indonesia. Kehadiran teknologi informasi merupakan bagian utama globalisasi. Pengaruhnya dapat menjadi positif atau 
negatif. Bagi pengelola madrasah perilaku proaktif dan positif dapat menjadi motivasi pendukung kemajuan madrasah. Kebalikannya, sikap negatif serta kontraproduktif dapat menjadi hambatan bagi kemajuan madrasah (Karni, 2009).

Pengelola lembaga pendidikan pada dasarnya mempunyai posisi dan fungsi yang strategis untuk mengendalikan lembaganya. Diantaranya adalah mempunyai kewenangan dan pemberi keputusan yang tidak ada pada guru. Kewenangan itulah yang mendorong pembaharuan dan perubahan melalui dukungan political will para pengelola. Madrasah yang mengalami penurunan kapasitas dan kualitas lazimnya kepala madrasah yang akan memperoleh kritik, padahal kondisi lemahnya pada berbagai aspek di madrasah, termasuk tenaga pengelolanya bahkan yayasan di dalamnya (Qomar, 2007).

Seiring perkembangan globalisasi, madrasah menghadapi tantangan di bidang manajerial yang cukup mendasar. Banyak pihak berharap supaya pendidikan dimenej menggunakan model "industri pendidikan" yang menjadi tren diera dewasa ini. Manajemen pendidikan bukan lagi dikelola dengan bentuk "manajemen sosial" yang ditandai dengan bebas dari kewajiban mencapai sasaran dan target serta bebas dari pengaruh subyek yang berwawasan "sempit". Semisal, pengelolaan manajemen madrasah dengan pendekatan kekeluargaan. Peran madrasah, pesantren atau sekolah Islam dituntut untuk menggunakan model manajemen strategik dengan merumuskan formulasi dan implementasi rencana untuk mencapai sasaran dengan baik (Robinson, 1997). Seperti diperhatikan, bahwa era globalisasi yang menjadi tren masyarakat perhatian orang terhadap sekolah unggul. Ini dimungkinkan karena adanya semangat mencari pendidikan alternatif yang lebih baik dan berkualitas. Oleh karena itu sudah semestinya pengelola lembaga pendidikan Islam dalam perspektif era global dengan mengembangkan dan mencari alternatif model pendidikan unggul terkait dengan peran pesantren, madrasah dan sekolah Islam yang ada di Indonesia ini.

\section{Kesimpulan}

Berdasarkan latar belakang di atas, pada prinsipnya madrasah semestinya mempunyai potensi besar untuk berkembang karena mempunyai social power yang dimilikinya. Madrasah yang eksistensinya berada di wilayah yang memiliki masyarakat muslim terbesar di dunia. Kondisi tersebut jelas mempunyai hubungan vertikal antara madrasah dengan masyarakat sebagai objek transformasi dalam mewariskan serta melestarikan eksistensi keyakinan dan nilai keIslaman.

Perubahan sosial timbul dengan berbagai bentuknya sangat dipengaruhi oleh berbagai faktor penyebab. Model perubahan sosial dapat dikaji dan kembangkan dengan sudut pandang tertentu agar tidak terjadi tumpang tindih. Ada beberapa sudut pandang yang dapat dipakai dalam rangka memetakan bentuk perubahan sosial di lingkungan madrasah. Aspek kecepatan perubahan; aspek besarkecilnya perubahan; maupun aspek motivasi. Perubahan sosial di madrasah bisa diklasifikasikan berdasar sifat, seperti kenyataan perubahan terjadi tidak hanya mengarah pada kemajuan, namun bisa juga mengarah kepada kemunduran. Dalam kaitannya dengan perubahan madrasah, bisa jadi mengalami kemajuan atau kebalikannya mundur di berbagai aspek.

\section{Daftar Pustaka}

Alam, T. (2012). Daru'l Uloom Madrassah Education in the UK: Alternating between Conservation and Change. Dissertation (London: Institute of Education University of London, 2012).

Azra, A. (2002). Jaringan Global dan Lokal Islam Nusantara. Bandung: Mizan.

Benda, H. J. (1987). Kontinuitas dan Perubahan dalam Islam di Indonesia. (T. Abdullah, Ed.). Jakarta: Pustaka Firdaus dan Yayasan Obor Indonesia.

Bower, J. L., \& Christensen, C. M. (1995). Disruptive technologies: catching the wave. Harvard Business Review 73, (1).

Brown, F. J. (1961). Educational Sociology (NJ). Tokyo: Charles E. Tuttle Company:, 153.

Bruinessen, M. van. (1994). Pesantren and Kitab Kuning: Maintenance and Continuation of a Tradition of Religious Learning" in Wolfgang Marschall (ed.), Texts from the Islands: Oral and written traditions of Indonesia and the 
Malay world: Ethnologica Bernica. Berne: University of Berne.

Dhofier, Z. (1985). Tradisi Pesantren:, Studi Tentang Pandangan Hidup Kiyai. Jakarta: LP3ES.

Esposito, J. L., Fasching, D., \& Lewis, T. T. (2007). Religion and globalization: World religions in historical perspective. Oxford: Oxford University Press.

Geertz, C. (1960). "The Javanese Kijaji:" The Changing Role Of A Culture Broke, "Comparative studies in society and history, II.

Hadi, A., Budianto, K., Otoman, Mikail, K., \& Syarifudin, A. (2020). The Dynamics of Ideal, Social, and Economic Changes of Madrasas in Indonesia. International Journal of Advanced Science and Technology, 29(9).

Hamad, I. (2004). Konstruksi Realitas Politik dalam Media Massa. Jakarta: Granit.

Hasyim, F. (2009). Strategi Madrasah Unggul. Yogyakarta: Prismasophie.

Hefner, R. W. (2007). Politik Multikulturalisme: Menggugat Realitas Kebangsaan. Yogyakarta: Institute for Multiculturalism and Pluralism Studies.

Horikoshi, H. (1976). A Traditional Leader in A Time of Change: The'Kijaji'and'Ulama' in West Java. University of Illinois at UrbanaChampaign.

Hussin, A. A. (2018). Education 4.0 made simple: Ideas for teaching. International Journal of Education and Literacy Studies, 6(3), 92-98.

Karni, A. S. (2009). Etos Studi Kaum Santri: Wajah Baru Pendidikan Islam. Bandung: Mizan.

Maksudin. (2008). Pendididikan Nilai Sistem Boarding School di Sekolah Menengah Pertama Islam Terpadu Abubakar Yogyakarta. Yogyakarta.

Mastuhu. (1994). Dinamika Sistem Pendidikan Pesantren. Jakarta: INIS.

Maulana, Z., \& Irfan, A. (2010). Jerat globalisasi neoliberal: ancaman bagi negara dunia ketiga. Jakarta: Riak.

Moedjiarto. (2007). Karakteristik Sekolah Unggul. Jakarta: Duta Graha Pustaka.

Puncreobutr, V. (2016). Education 4.0: New challenge of learning. St. Theresa Journal of
Humanities and Social Sciences, 2(2).

Qomar, M. (2007). Manajemen Pendidikan Islam. Jakarta: Erlangga.

Reynarah, M. D. (2015). Robot VS Manusia, Ini pesan Jack Ma dalam menghadapinya. Diambil dari https://link.medium.com/RKpzSe6yL6

Robinson, P. (1997). Manajemen Strategik, Formulasi, Implementasi dan pengendalian. (A. M. Maulana, Ed.). Jakarta: Binarupa Aksara.

Shahroom, A. A., \& Hussin, N. (2018). Industrial Revolution 4.0 and Education. International Journal of Academic Research in Business and Social Sciences, 8(9). https://doi.org/10.6007/IJARBSS/v8-i9/4593

Sivathanu, B., \& Pillai, R. (2018). Smart HR 4.0 how industry 4.0 is disrupting HR. Human Resource Management International Digest, 26(4), 7-11. https://doi.org/10.1108/HRMID04-2018-0059

Steer, L. (2016). The learning generation: Investing in education for a changing world. New York: International Commission on Financing Global Education Opportunity.

Woodward, M. R. (1996). Talking across paradigms: Indonesia, Islam, and orientalism. Toward a New Paradigm: Recent Developments in Indonesian Islamic Thought, Temple: Arizona State University.

Zasmadi. (2002). Modernisasi Pesantren, Kritik Nurcholish Madjid Terhadap Pendidikan Islam Tradisional. Jakarta: Ciputat Press. 
Kesiapan Madrasah untuk Keberlanjutan Proses Pendidikan Perspektif Teologi Perubahan di Era Industri 4.0 